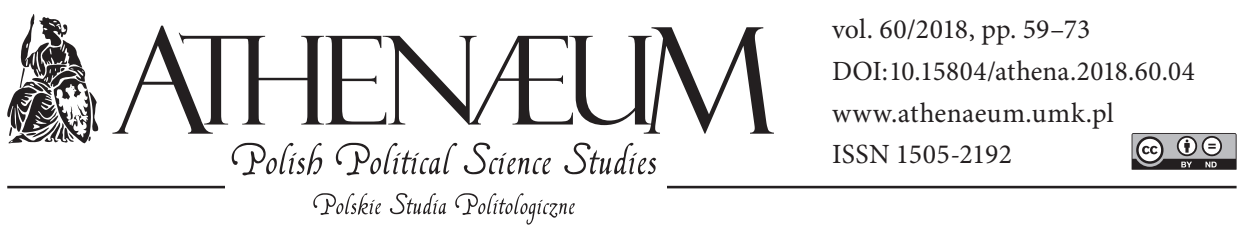

\title{
POLITICAL SCIENCE CONCERNING RELIGION IN THE PERSPECTIVE OF MODERATE METHODOLOGICAL NATURALISM
}

\author{
POLITOLOGIA O RELIGII W PERSPEKTYWIE \\ UMIARKOWANEGO NATURALIZMU METODOLOGICZNEGO
}

Łukasz Młyńczyk* (1)

\begin{abstract}
The aim of the article is to define the methodological status of the proposed new sub-discipline of political sciences - the political science of religion (politology of religion). The diagram of naturalism adopted in the text indicates the choice of the perspective of cognition for an alliance of religions and politics as a single social and political phenomenon. The position expressed in the text aims to find a common knowledge base for the two most important social phenomena. The presented postulate takes into account the combination of knowledge in the field of political sciences and theology, sociology of religion, religiousness or history with the classical methodology of sciences, characteristic for mathematical natural science.
\end{abstract}

Keywords: political science of religion (politology of religion), naturalism, understanding naturalism, antinaturalism, understanding sociology, the political
Celem artykułu jest próba określenia metodologicznego statusu postulowanej nowej subdyscypliny nauk o polityce - politologii religii. Przyjęty w tekście schemat rozumiejącego naturalizmu wskazuje wybór perspektywy poznania dla sojuszu religii i polityki jako jednego zjawiska społecznego-politycznego. Stanowisko wyrażone w tekście zmierza do znalezienia wspólnej płaszczyzny wiedzy dla dwóch najważniejszych zjawisk społecznych. Zaprezentowany postulat uwzględnia łączenie wiedzy z zakresu nauk o polityce oraz teologii, socjologii religii, religioznawstwa czy historii z klasyczną metodologią nauk, charakterystyczną dla zmatematyzowanego przyrodoznawstwa.

Słowa kluczowe: politologia religii, naturalizm, rozumiejący naturalizm, antynaturalizm, socjologia rozumiejąca, polityczność

* University of Zielona Góra, Institute of Political Science. 


\section{ASSUMPTION}

Our actions are determined by the cause (causal explanation) and purpose (intentional explanation), hence the researcher of political phenomena may impose his or her own cognitive perspective on religion in the form of understanding naturalism, expressed by an integral explanation of political phenomena (including religion) in the form of synthesis of understanding sociology (Weber) and naturalism. The assumptions of the general methodology of science push the science of politics to the periphery of science, imputing a relatively low utility value of political science knowledge. If we assume that the consequence of research processes is to acquire the knowledge of utilitarian par excellence, the effect of applying which will be the ability to solve problems falling within its domain, then here appears, according to many, the obvious problem for political science. It is not about the ability to fulfill the material needs of society, but certainly about the reference to the problem, located in a specific unit of time (temporally) and strictly materially. In purely naturalistic terms, it is reasonable to say that political science using diverse research instruments may give the impression of being pre-paradigmatic (pre-scientific; Bachryj-Krzywaźnia, 2016). The explanation and understanding of political phenomena and processes can be determined by the effect of scientific inquiry in the area of interest to us. Interpretationism, which is an interpretation of the anti-naturalistic standpoint, presupposes the necessity of separating the natural sciences and social sciences, questioning the naturalistic judgement about general and universal validity of the laws of natural sciences, which are written on the pages of the general methodology of sciences. Intuitions suggest the choice of a position having its essence in an opposite type, so the naturalist is everything that one does not want to be an anti-naturalist, and vice versa. At the same time, it will be quite obvious that both rules have identical scientific rules. Thus, it is not anti-naturalism only a humanistic reflection, but an expanded form of interpretation, based on the methodology of the sciences, only that its generality in the form of rules and so is derived from the mathematized natural science. It is then legitimate to speak about political science as a discipline of science, in a methodological sense, not only an institutional one. As a social science, it has a poly-paradigmatic character, which means that theories at the same level of science development correspond with each other at the same time (Węsierski, 2011). The inability to refer to one comprehensive theory available in the social sciences does not prejudge the lower theoretical status of politics, because competing to explain the phenomenon 
of approach consequently creates a complementary approach to it. Of these elements of the theory, the dialectic synthesis is not so much produced as is the overlap of explanations specific for social sciences, where one theory becomes more precise in explaining phenomena as long as it is accompanied by another, creating a new interpretation. The status and content of the theory does not change, but its range of action is shifted.

Contemporary problems investigated by political scientists, such as biopolitics, neuropolitology, evolutionary theory of politics, often reach to the instruments of medicine, biology, psychology or recently also physics. Therefore, the sine qua non condition is inference regarding the rules of the natural sciences. The essence of this was widely recognized in Poland by the Poznan methodological school, with the humanistic interpretation of Jerzy Kmita or the historiosophy of Leszek Nowak. Kmita assumed a cognitive situation in which the interpretation would be an effect of deductive inference in the humanistic sciences, and on its virtue the universality of laws of nature reduces the assumptions of the rationality of the causative entity (Grad, 2012). For Nowak, in contrast to Karl Popper and his theses included in Nędza historycyzmu [The Poverty of Historicism], the essence of discovering the laws of history was the use of the usual scientific method, i.e., idealization, where accepted hypothetical models explained the simple relationship possible between as few variables as possible, including the clause ceteris paribus (Nowak, 2011). Jerzy Topolski promoted the directive of integral explanation in the area of humanities (including political sciences). He combined the humanistic interpretation with deductive reasoning. The essence of this boiled down to getting an understanding of history by explaining it. This will be achieved when we combine the methodological individualism that gives us information about the intentions and preferences of subjects with the Weberian ideal type of rational action, which let us gradually strive to find the correctness of the historical process as the effect of knowledge about the causes. The presented article reaches into these traditions, and the attempt will be made to determine the epistemological status of the proposed subdiscipline of political science - political science of religion. The aim will therefore be to set out a framework for political science in relation to the concept of religion, understood as a social phenomenon. 


\section{EXPLANATION}

Our actions always have a purpose similar to creating a world by God, so creating a political organization do we de facto create the world? In the case of using Ockham's razor and striving for the rationalization of the (temporal) political world, it would probably be necessary to disregard the religious (transcendent) world, because a world without God and religion would be rational theoretically and politically. Can political science, therefore, recognize religion only as a political phenomenon ${ }^{1}$, unless it wants to refer to theism (what is supernatural) by choosing a relation to the political (moderate methodological naturalism)? In adopting religion in the world of the study of political scientists, we must realize that the simplified cognitive model refers to phenomena and processes to which we give a political character, and its basic function will be the interpretation of actions of entities with a possible cause and purpose. In spite of any fears, religion can be regarded as a natural phenomenon, available only in the human world, and thus subject to the laws of physics and biology. Assuming that religion will be a social phenomenon, deprived of uniqueness, which collectively acquires political knowledge through selecting the features of the political, talking about the need for epistemological, ontological and methodological separation of the specificity of political religion loses its primary arguments. One could hypothesize here that the shaped concept of political science in its final scientific version will always make a regression to political theology. Political scientists investigating the influence of religion should look for an answer to an important dilemma expressed in the possible elimination of the eschatological context from their considerations or give it an ideological function. The second alternative will appear when we acknowledge the fear of eternal condemnation (hell) as a real social fear, we force politics (politicians) to declare security (e.g., Locke's security agency) against this threat, which will also be on the side of a particular religion (set of beliefs - reductio ad christianum) and breaking the rule of religious freedom (Dworkin, 2014). This is because we use the social and utilitarian definition of religion, the essence of which is based on the understanding of the circumstances of its impact on the life of a specific community, which may consequently become a political organization of society. One can set religious and

1 “The syndromic quality of political phenomena and their relationship with virtually all spheres of social life require a comprehensive and multi-faceted coverage of the subject of the study" (Węsierski, 2011). 
anti-religious motivations that are competing against each other. However, we are talking here about the dominant role of natural religions in the political order, as evidenced by the British enlightenment of the important function of creating public order, also with the participation of religious dissident sects, for which Adam Smith emphasized strict morality (Himmelfarb, 2018). What deserves attention is that deists/skeptics such as Smith, even if they questioned religion as a source of morality, they nevertheless considered its alliance natural with human innate morality (Himmelfarb, 2018). Taken for the obvious by many, the primacy of reason in the case of British Enlightenment has never been questioned, but on the basis of science, the coincidence of religious utility has been suggested, reinforcing the general principles of good and evil. Even if we are skeptical about the existence of the "moral sense", the fact of such human sensibilities (virtues) that bind their usefulness to the obtained benefit (Locke) must arouse reflection. Human tendencies described as natural, however, differ from predispositions, which can be defined as a function of political behaviors (including actions). The inclinations of human nature, which on political grounds can be found even in the existing certain moral feelings creating one society, remaining in the domain of natural law can be transferred to religion as a derivative of natural moral states that materialize in the form of human behavior, including religious. Indirectly, this is the reason why religion included in the framework of social cognition cannot free itself from politics. By illustrating this state, we can talk about subordinating religion to politics because in the mundane world (available to political scientists) they are recognized as social phenomena, not transcendent phenomena. Therefore, the politicization of religion, that is, the giving of its function to the political, is the highest dimension known to humanity today (Młyńczyk, 2015). Therefore, the relevance of religion has a potentially marginal value.

Of course, it should be stipulated that we do not have credible evidence that the political format of religion, for example, political action to implement the "Kingdom of God on Earth" (which is not a universal religious expectation), always makes use of it. The intermediate state, between the object and subject politicization (descriptive category) of religion, may mean the alternative pursuit of a valuable life by religious people and atheists and agnostics, expressed by taking just political decisions. In turn, a strictly subjective state can be found in the functioning of a political organization that is merely a function of religious determinism (autotelic postulate). Indication of the primary character of one of the above phenomena will be a choice based on belief, and not a choice of 
a specific research program (commitment). It is not excluded that the adoption of a strategy within a selected research program, especially at the level of political science, may have a relevant status when we assume that the conclusions lead to the explanation and prediction of an identical phenomenon. This is how the established coincidence regulates only the issues of higher cognitive utility from the perspective of the cognizer, and not the object of cognition. In both of these cases, the consequence may be the creation of a belief among the recipients who may lose the ability to decide whether the knowledge provided is independent of his or her conviction. Bearing in mind the political science objection that it can only be a verbal science, and at the same time referring to Popper's criticism of neo-positivism (post-positivism), we must consider the dilemma regarding the possibility of obtaining social knowledge (political science), free from contexts based on political consensus. The basic weakness of political science as a discipline of social sciences in relation to the assumptions of the theory of science made by Karl R. Popper could be its forced absence in the theory of the three worlds (Popper, 2012). Of course, this is not about the fact of ignoring the science of politics, but about a certain general scientific inability of the social sciences. It is expressed in the impossibility of using knowledge in the field of social sciences while trying to solve social problems, because Popper's theory overlooks the social world (Grobler, 2016). But does political science want and can deal with this indirect lack of inclusion in what is essentially scientific? The components of knowledge may, in certain circumstances, not enter into the period of one's opinion - epistemology without the cognitive subject (Grobler, 2016): Popper gave an example of knowledge left in books after the destruction of man. In such a case, religious axiology (principle) could similarly be independent of the existence of God (the third world of Popper). Observation of political phenomena as products of our thinking, which are not naked facts, leads us to search for confirmations of accepted assumptions. Thus, it is possible to determine the statistical motivations of human actions and social behavior through their purpose and intentions (maximizing individual usability), gaining their apogee in the content of the political (Młyńczyk, 2015). According to the assumptions of naturalism, human aspirations and desires materializing in their behavior and natural phenomena are identical in terms of their causal explanation. If the pursuit of science is the discovery of rights, then it is analogous to social rights, although the latter are not universal and depend on the rules prevailing in society or cultural norms (Grobler, 2006). Statistical generalizations or statistical laws, as well as historical generalizations and qualitative theorems 
are mainly available in the social sciences, so there are no strictly general laws (Węsierski, 2011). At this point, political science can benefit from the synthesis of a naturalistic and understanding approach (understanding naturalism), proposed to social sciences by Adam Grobler (2006). The attempt to place the matter of political science in Popper's 2 and 3 world would be based on the imitative experiences - goals and intentions of the observed entities (World 2) and the statistical repeatability of these goals and intentions expressed by objectified knowledge (World 3; cf. Młyńczyk, 2015). Explanation of political phenomena and processes within the framework of political science would have to assume a gradual neutralization of (second-world) imitative experiences expressed in scientific empathy (Verstehen) and incarnation (Dilthey, 1987), instead of reconstructing the objective (third-world) problem situation through its rational solution (Grobler, 2006). We can see, therefore, that all attempts by the researchers of political science in the context of imitation (World 2) allow only such an understanding of the manifestations of religion in political life, which was previously given the expected and highest priority. This statement in itself is not a complaint, because we do not decide whether it is about appreciation or depreciation of religious ideas. By analogy, we do not separate believers, and atheists and agnostics. Such a perspective allows us to understand, stopping the possible chance of explaining the problem closer to scientific objectivity and we do not claim anything more than that. To this extent, we are referring to the re-linking of human acts and social processes (Topolski, 1978). The goal people are trying to achieve can be determined by a certain law in the area of repeated individual desires and judgments (Młyńczyk, 2015), per analogiam to the physical order of the universe. If there are definitely no bare facts (Heller, 2016), then our action (conduct) results from "the theorization of observation", and everything contains the primary cause, we strive to maximize the utility of the individual, which in political science can be expressed with temporality (autotelicity) and/ or eschatology. Deprived of social contexts, eschatology in terms of metatheory determines what is fundamental in religion, thus eliminating the temporal nature of politics in a strictly methodological (naturalistic) dimension. The rational approach to a given goal stops at what is temporal, and therefore at the highest available point is based on the political.

Max Weber identified human action with behavior (understanding sociology) when, with an internal or external act, one or many acting, it binds a subjective sense, turning into social action, when the intentional sense of the acting person(s) is connected with the behavior of other people and he or she is aware 
of it (Weber, 2002). In the case of naturalism, the action results from a repetitive law (cause and effect relationship). For understanding sociology, we have an imitative experience, in which action results from the recognition and not the functioning of laws (purposefulness and intentionality). It should be stressed that intention cannot be the cause of action; while remaining its component, it becomes something separate from the effect. As a consequence of capturing this moderately naturalistic moment of cognition, we can diagnose that human actions (partly imitative) are not motivated by rights but by an understanding of these laws. The whole is expressed by the synthesis of naturalistic (laws) and anti-naturalistic elements (understanding of laws) in a closed deductive integral assumption (see diagram). The political science of religion seems to us paradoxically practical, because in its empiric there are specific problems to solve. It results directly from the extended by the applicability condition of the definition of knowledge, where "to know something means, among others, being able to use your message to solve a practical or theoretical problem” (Grobler, 2016).

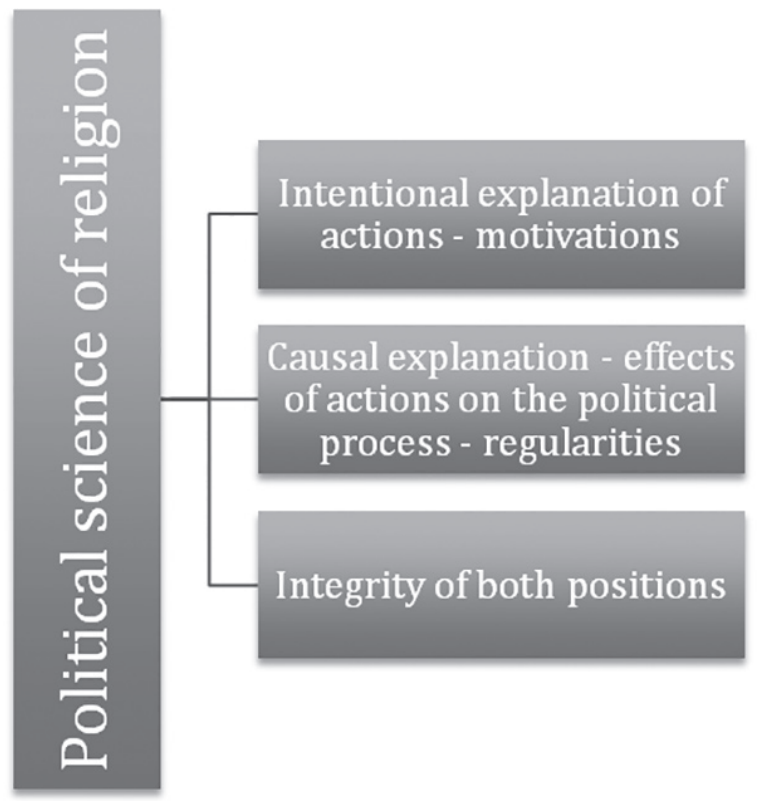

Diagram 1. The cognitive scheme of political science of religion

Source: own study. 


\section{MODERATELY NATURALISTIC DOUBTS}

Why does political science need religion as it only hinders reaching the scientific truth? Optimizing of the political order does not guarantee the choice of a religious world, in this approach a rational, theoretically and politically, would be a world without God and religion. The null hypothesis would therefore assume that naturalism, expressed in the theory of evolution by means of natural selection, is a scientific theory par excellence, which would mean explaining the fate of the world without the influence of God. At the same time, if we assume that the original cause existed first (case and necessity), then the Ockham's razor will not apply (Dennet \& Plantinga, 2014). Dworkin points out that usually in the political order people choose a religious world entering into conflict with atheists, because the latter represent a world that is morally unacceptable to the former, hence the conflict runs between what is natural and what is defined as the world of values (Dennet \& Plantinga, 2014).

The dispute between naturalists and advocates of the intelligent design theory can also be inspiring for political science itself. Scientists-naturalists in the US pay a lot of attention to pointing out the errors of the biblical approach to creation, which a few years ago was considered cognitively unfounded (Dennet \& Plantinga, 2014). It is possible to find the answer to the regret of the famous physicist Richard P. Feynman, who claims that people separated from scientific debate believe in supernatural phenomena, because no one is working on these problems with them (Feynman, 2005). The basic doubt concerns the issue of understanding religion (explanation vs understanding) as a natural phenomenon, through the function of making fair political decisions (Dennet, 2017). Unless, of course, we consider religion a natural phenomenon, available exclusively in the human world, and therefore subject to the laws of physics and biology (Dennet, 2017). In a Puritan view, the religious attitude contradicts naturalism, recognizing the world of values as completely independent. Then the solution will be to limit the recognition of political science of religion by recognizing its object of cognition as a social phenomenon, based in part on the achievements of natural sciences and psychology. At this point, not yet reducing religion, one might wonder whether it would be legitimate to study religion in social life through roles that religious people as well as atheists and agnostics attribute to it. We are facing them in the above axis, whose values oscillate around the opposition: smaller or larger implementation/exclusion. The causal link in physics requires space and time, and so does political science. 
Let us repeat then: can political science recognize religion only as a political phenomenon, unless it wants to refer to theism (what is transcendent), reducing its socio-naturalistic manifestations to describe what is political (methodological naturalism)? Can we do in political science of religion without a specific reference to the problem of interfering with God in politics (the null hypothesis)? It is not our goal to carry such proof, but to draw political consequences from a world that contains the purpose and cause of its creation. The political consensus on the presence of God is in the public interest. In addition to the eschatological goals of believers, we have a justification for the religious position of atheists for their earthly life. The whole is contained in direct impact on the political organization of society. Next we have intermediate goals, expressing the scientific dispute between naturalists and theists, guaranteeing them the desirability of searching for their own justifications. An indirect benefit may be the creation of institutional order, which to the highest degree satisfies the needs of the society which it serves (evolutionary theory of politics). Political activities replacing divine intervention are in the interest of the opponents cited, because they prove the lack of necessity. Taking human existence as temporal, in the opinion of Mark Lilla (2009), the implementation of political goals will make it impossible to refer to revealed knowledge, that is, the unlawful knowledge, and political institutions separated from the problem of eternity will turn towards temporal. Nevertheless, people who believe in revelation take "earthly" decisions with specific political consequences.

Can basic concepts appear in political science, for example, power, political order, to avoid regressus ad infinitum? Dworkin believes, unlike Popper, that there is no absolute, infinite regress, because everything that exists, exists for some reason, so there must also be "some" primary cause. In the social sciences, there are no axioms, as in the case of natural sciences; or can the law of political science of religion have the status of universal laws? The universality of results is blocked intentionally, becoming a trace of inductive reasoning. This happens when the probability of successfully building a hypothesis depends on previous empirical knowledge, where relationships between, in our opinion, similar phenomena are a component of inductively acquired confirmations (Grobler, 2006). This leads inevitably to regress to infinity. Understanding what we use forces us to logically justify the theorem, which also requires justification, and that immediately needs the next justification. As the creator of falsificationism claimed, sentences can only be justified by sentences (Popper, 2002). When the justification is no longer justified, "arbitrary power" appears, and this enables us 
to proclaim that "it is so" (Leder, 2016). Perhaps then, religious dogma is not so much mediated in political science as its transcendence (divine arbitrariness) is borrowed. There is a kind of tacit agreement between physicists (Heller, 2016), but nowadays we are dealing with its mutation in the form of a consensus that serves to achieve political goals resulting from research in the natural sciences. This happens due to giving nature rights to the laws of nature, whose management is dealt with by politicians. Andrzej Leder (2016) reconstructs the $20^{\text {th }}$ century scheme of understanding social sciences, which we could call the fear of naturalism, and it results from a reducing look by articulating the negative effects of social cognition affecting the problem of "purity of race" and "perfect construction" (Leder, 2016). It is difficult to reproach these conclusions, especially when we realize their fusion with time and space (generalizations). It will certainly be another problem recognized as a phenomenon dominated by the political science of religion.

From the above, one more analytical circumstance, boiling down to the awareness of the scale of cognitive predilections among researchers in political science, is evident. Of course, the advantage is the inability and purposelessness of separating the context of discovery and the context of justification (Heller, 2016). What is more, we do not expect researchers to isolate their emotions, assumptions, views, make-up or just contextual dependence (Taleb, 2013). This may mean that some subjectively legitimate missionary context cannot be eliminated (cf. Michalak, 2015), both in relation to the strictly understood theological rules, as well as in their political secularization, as a format for eliminating the negative impact of undesirable phenomena and processes limiting the rights of some people by others.

One could consider a slightly different reference to the recommendations of the economy of thinking here. Therefore, it is not a question of getting rid of the explicative features of religion in its marriage with political science, but it is rather about the economy of epistemological rules. There is a surplus of opinions expressed by people who are openly committed, trying to get the desired effect by imposing the elements interpreted along with their correct interpretation. They achieve the influence expressed by the closure of the debate according to the recommended criteria. They do not go beyond this circle, wading more and more clearly in the antinomy. Dialectics stops them in a place where the knowledge of politics requires theoretical explanations, and not the duration of the claimant reductionism. The political trait ceases to have its properties when it is forced to represent the problem only in the form of a demand. 


\section{CONCLUSIONS}

The specific cognitive position presented in the article concerns the directions of explanation for the subdiscipline - political science of religion, postulated in the sciences of politics. Undoubtedly, the reflection on religion coincides with that relating to politics from the very beginning of their existence. What is more, the political science literature, rich in the domain of political scientists, to a large extent has illustrated the problem of God and religion in the social and political life of humanity. Therefore, talking about the universal theoretical key for explaining the relationship between politics and religion from the point of view of the theory of science is groundless. We are, of course, fully aware of the fact that the highest priority has been given in political science to political theology, but it cannot be considered, in spite of enormous achievements, for a finite empirical theory whose status would be widely accepted. Proposed positions must take into account the factual methodological dependence of social sciences and the so-cited science on politics, where the quality of the theory and its laws closely depends on the existence and reference to another, often equivalent, and differently interpreting the empiric policy. A look at religion as a social phenomenon, considered by political science, may seem to suggest a conflict with people who define themselves as religious, less often anti-religious. This is due to the acknowledgment of its dominion as a non-alternative social model, which some unconditionally accept, others, in turn, firmly reject. For some, the very scientific reduction of cognition, expressed by the "disenchantment" of religion, is an incentive to fight for the right to publicly profess faith not so much in public space as in the scientific circuit. Atheists/agnostics usually use the appearance of expressions of a particular religion as an opportunity to demonstrate the oppressiveness of the codified system of values, contrary to their postulated freedom. Both these positions are reflected in the political literature, in which there is a large representation of doctrinaire positions, and they are given a strictly scientific dimension not by virtue of the adopted methodologies, but due to the affiliation of their representatives. The ideological and apologetic trend is dominant here. Meanwhile, the only thing a political scientist could do in this relationship was to show a polemical position on the basis of the general methodology of science. In the case of political science, we are forced to take into account all diseases resulting from adolescence. This does not directly mean that we are dealing with a poor theoretical reflection, but rather with the fact of a strong inclusion of the new subdiscipline, when the guards of the new 
scientific niche do not keep proper vigilance. Then comes the effect that Polish political science has struggled with from its institutional origins, and hence the secondary circulation of people of science, transferring their previous scientific achievements. The flow of a large number of theologians, religion specialists, sociologists, and historians of religion and church is not a problem in itself, but raises doubts when the term "political science of religion" becomes just an overly wide umbrella.

\section{REFERENCES:}

Bachryj-Krzywaźnia, M. (2016). Filozoficzne ramy i przesłanki zróżnicowania podejścia interpretacjonistycznego. Wrocławskie Studia Politologiczne, 21, 7-23. DOI: 10.19195/1643-0328.21.1.

Bloom, A. (2012). Umysł zamknięty: o tym, jak amerykańskie szkolnictwo wyższe zawiodto demokrację i zubożyło dusze dzisiejszych studentów. Poznań: Wydawnictwo Zysk i Ska.

Dawkins, R. (2012). Samolubny gen. Warszawa: Prószyński i S-ka.

Dennett, D.C. (2017). Odczarowanie. Religia jako zjawisko naturalne. Warszawa: Państwowy Instytut Wydawniczy.

Dennet, D.C., \& Plantinga, A. (2014). Nauka i religia: czy można je pogodzić. Kraków: Copernicus Center Press.

Dilthey, W. (1987). O istocie filozofii i inne pisma. Warszawa: PWN.

Dworkin, R. (2014). Religia bez Boga. Warszawa: Wydawnictwo Aletheia.

Eibl-Eibesfeldt, I. (2017). Love and Hate: The Natural History of Behavior Patterns. London and New York: Routledge.

Feynman, R.P. (2005). Przyjemność poznawania. Warszawa: Prószyński i S-ka.

Gazzaniga, M.S. (2011). Istota człowieczeństwa: co sprawia, że jesteśmy wyjątkowi. Sopot: Smak Słowa.

Gazzaniga, M.S. (2012). Przyrodniczy umysł: biologiczne korzenie myślenia, emocji, seksualności, języka oraz inteligencji. In: L. Balcerowicz (ed.), Odkrywając wolność: przeciw zniewoleniu umysłów (pp. 947-962). Poznań: Zysk i Ska.

Grad, J. (2012). Jerzy Kmita (1931-2012) - wspomnienie. Nauka, 3, 177-188.

Grobler, A. (2006). Metodologia nauk. Kraków: Znak.

Grobler, A. (2016). Dwa pojęcia wiedzy: w stronę unifikacji. Przegląd Filozoficzny. Nowa Seria, 25(1), 141-160.

Heller, M. (2014). Granice nauki. Kraków: Copernicus Center Press.

Heller, M. (2016). Filozofia nauki. Kraków: Copernicus Center Press.

Heller, M., \& Życiński, J. (2016). Dylematy ewolucji. Kraków: Copernicus Center Press. Himmelfarb, G. (2018). Drogi do nowoczesności: brytyjskie, francuskie i amerykańskie oświecenie. Warszawa: Teologia Polityczna. 
Hodgson, G.M. (1998). On the Evolution of Thorstein Veblen's Evolutionary Economics. Cambridge Journal of Economics, 22(4), 415-431. DOI: 10.1093/oxfordjournals.cje. a013726.

Hodgson, G.M. (2002). Institutional Economics and the Problem of Historical Specificity. In: H.H. Nau, \& B. Schefold (eds.), The Historicity of Economics: Continuities and Discontinuities of Historical Thought in $19^{\text {th }}$ and $20^{\text {th }}$ Century Economics (pp. 92-125). Berlin: Springer.

Judt, T. (2011). Źle ma się kraj. Rozprawa o naszych współczesnych bolączkach. Wołowiec: Wydawnictwo Czarne.

Kmita, J. (1973). Wykłady z logiki i metodologii nauk. Warszawa: Wydawnictwo Naukowe PWN.

Lacan, J. (2017). Triumf religii. Warszawa: PWN.

Leder, A. (2016). Rysa na tafli: teoria w polu psychoanalitycznym. Warszawa: PWN.

Lilla, M. (2009). Bezsilny Bóg. Religia, polityka i nowoczesny Zachód. Warszawa: Wydawnictwo AB.

Masters, R.D. (1991). Polityka jako zjawisko biologiczne. In: B. Szacka, \& J. Szacki (eds.), Człowiek, zwierze społeczne (pp. 127-159). Warszawa: Czytelnik.

Mazurkiewicz, P. (2017). Europa jako kinder niespodzianka. Kraków: Ośrodek Myśli Politycznej.

Michalak, T. (2012). Ekonomiczna teoria demokracji Anthony'ego Downsa. In: J. Wilkin (ed.), Teoria wyboru publicznego. Główne nurty i zastosowania. Warszawa: Wydawnictwo Naukowe Scholar.

Michalak, R. (2014). Wstęp. Politologia religii - postulowana subdyscyplina politologii. In: R. Michalak (ed.), Religijne determinanty polityki (pp. 5-11). Zielona Góra-Sieniawa Żarska: Wydawnictwo Morpho.

Michalak, R. (2015). Wstęp. O politycznych ścieżkach religijności i dychotomii koniunktury badawczej politologii religii. In: R. Michalak (ed.), Polityka jako wyraz lub następstwo religijności (pp. 5-10). Zielona Góra-Sieniawa Żarska: Wydawnictwo Morpho.

Młyńczyk, Ł. (2015). Między kreatywnościa a próżnowaniem. Polityczność dwóch typów idealnych. Warszawa: Dom Wydawniczy Elipsa.

Młyńczyk, Ł. (2017). Co lub kogo falsyfikuje Popper. Problem ścisłej wiedzy politologicznej. Studia Krytyczne, 4, 13-25.

Nowak, L. (1991). U podstaw teorii socjalizmu. Vol. 1: Własność i władza: o konieczności socjalizmu. Poznań: Wydawnictwo Nakom.

Nowak, L. (2011). Dogmat „ukąszenia Heglowskiego”. In: L. Nowak [K. Brzechczyn, (ed.)], Polska droga do socjalizmu. Pisma polityczne 1980-1989. Poznań: IPN.

Nowak, M. (2009). Instytucjonalizmy w socjologii i ekonomii. Problem i jego konceptualizacja. Poznań: Wydawnictwo Naukowe Uniwersytetu im. Adama Mickiewicza.

Osiatyński, W. (2009). O prymacie etyki: rozmowa z Walentyną Leonowicz. In: W. Osiatyński, Zrozumieć świat: rozmowy z uczonymi 25 lat później. Warszawa: Czytelnik.

Ossowski, S. (2001). O osobliwościach nauk społecznych. Warszawa: PWN. 
Popper, K.R. (1999). Nędza historycyzmu. Warszawa: PWN.

Popper, K.R. (2002). Logika odkrycia naukowego. Warszawa: PWN.

Popper, K.R. (2012). Wiedza obiektywna: ewolucyjna teoria epistemologiczna. Warszawa: PWN.

Ryan, F. (2017). Tajemniczy świat genomu ludzkiego. Warszawa: Prószyński i S-ka.

Schmitt, C. (2000). Pojęcie polityczności. In: C. Schmitt, Teologia polityczna i inne pisma (pp. 31-42). Kraków-Warszawa: Społeczny Instytut Wydawniczy Znak.

Taleb, N.N. (2013). Antykruchość: o rzeczach, którym służa wstrzassy. Warszawa: Kurhaus Publishing.

Tarnawski, E. (2003). Kapitalizm jako władza, polityka jako biznes: ewolucyjna teoria polityki Thorsteina Veblena i lekcja z rosyjskiego kapitalizmu. In: J. Osiński (ed.), Wzrost gospodarczy i rozwój społeczny jako paradygmaty współczesności (pp. 127-159). Warszawa: Polskie Wydawnictwo Ekonomiczne.

Topolski, J. (1978). Rozumienie historii. Warszawa: Państwowy Instytut Wydawniczy.

Veblen, T. (1898). Why Is Economics Not an Evolutionary Science? The Quarterly Journal of Economics, 12(4), 373-397. DOI: 10.2307/1882952.

Veblen, T. (2008). Teoria klasy próżniaczej. Warszawa: Muza.

Weber, M. (2002). Gospodarka i społeczeństwo: zarys socjologii rozumiejacej. Warszawa: Wydawnictwo Naukowe PWN.

Węsierski, M.R. (2011). Problemy integracji wiedzy a badanie zjawisk politycznych. $W$ stronę idei jedności nauki. Warszawa: Semper.

Wielomski, A. (2017). W poszukiwaniu Katechona. Teologia polityczna Carla Schmitta. Radzymin: Wydawnictwo von Borowiecky. 